\title{
Flame retardants, their beginning, types, and environmental impact: a review
}

Ali I. AL-MOSAWI

PhD in polymers Engineering at Institute of Ceramic and Polymer Engineering, Faculty of Materials Science and Engineering, University of Miskolc, Hungary. Research Interests: Polymers, Composite Materials, Rubber Technology, Flame Retardants, Materials Testing, Materials Processing

ALI I. AL-MOSAWI - Institute of Ceramic and Polymer Engineering, University of Miskolc, Hungary - aliibrahim76@yahoo.com, alialmosawi76@gmai.com

Érkezett: 2020. 07. 25. - Received: 25. 07. 2020. - https://doi.org/10.14382/epitoanyag-jsbcm.2022.01

\begin{abstract}
Flame retardants have made the world safer by significantly reducing fire risks and reducing human and material losses. At the same time, however, environmental problems have been created and their impact on health, as the compounds that make up the flame retardant are heavy metals. Therefore, in order to make these materials safer, efforts must be focused on using environmentally friendly ones. Furthermore, this green approach must be in line with the laws and legislation developed by many countries due to the recommendations of environmental institutions that warned of the dangers of continuing to use flame retardants containing heavy metals. Not only that but all government and private institutions and civil facilities must be obliged to use flame retardants as a primary building material. This review will focus on the most critical developments that flame retardants have experienced and their impact on the environment and health through their types and mechanism of action.
\end{abstract}

Keywords: flame retardants, historical review, environmental considerations

Kulcsszavak: égésgátlók, történeti áttekintés, környezetvédelmi megfontolások

\section{Historical overview of flame retardants}

Flame retardants are defined as chemical agents that can withstand direct flame by stopping flame entry into the material, controlling its spread, and even extinguishing utterly. These materials can be added during or after the products' fabrication for burning protection. The development of flame retardants allowed the safe usage of fabrics that cause flammable behaviour by reducing flammability and reduce the rate of burning. The compounds of phosphorus, nitrogen, chlorine, bromine, boron, and antimony are ones of the most widely used for flame retarding [1-9]. Many materials with flame retardant properties have been known for many centuries. The earliest use of flame retardants was by the eastern civilizations, specifically by the Egyptians and Chinese. Where about 3000 years ago, the ancient Egyptians were soaking grass and reed in seawater before they used it for roofing, so when these grass and reed dry, the mineral salts will crystallize and act as a fire retardant. The Egyptians and Chinese also used alum and vinegar to paint timbers in temples to protect them from the fire [10-13]. The first attempts to use flame retardants by Western civilizations were by the army of the Roman Empire when they besieged the city of Piraeus about $87-86$ B.C. The Roman army painted siege towers made of wood with a mixture of alum, vinegar, and clay to protect it from burning by the fire of city defenders. The Roman flame retardant mixture was developed from what the ancient Egyptians used.

Although the ancient civilizations did not have the necessary equipment to analyze these materials' components, they pay attention to the nature of these substances acting as retardants. The discovery of the flame retardancy properties of these materials was through coincidence. Still, they inevitably conducted some practical experiments, even if primitive, to prove these materials' effectiveness in fire protection, in addition to searching for other materials with the same properties. Indeed, this led to the development of testing devices to detect these materials [14].

\begin{tabular}{|c|c|c|}
\hline Material & Used by & Date \\
\hline $\begin{array}{l}\text { Potassium } \\
\text { Aluminium } \\
\text { Sulphate (Alum) }\end{array}$ & $\begin{array}{l}\text { The Egyptians have used Alum and } \\
\text { Vinegar to reduce wood flammability }\end{array}$ & 450 B.C. \\
\hline Vinegar & $\begin{array}{c}\text { The Egyptians and Chinese used } \\
\text { painted timbers by vinegar to increase } \\
\text { their resistance to burning }\end{array}$ & 360 B.C. \\
\hline $\begin{array}{l}\text { Alum, Vinegar, } \\
\text { and clay }\end{array}$ & $\begin{array}{l}\text { The Roman army painted the wooden } \\
\text { siege towers with alum, vinegar, and } \\
\text { clay to protect them from burning when } \\
\text { they besieged Piraeus }\end{array}$ & 87-86 B.C. \\
\hline $\begin{array}{l}\text { Clay-Gypsum } \\
\text { Mixture }\end{array}$ & $\begin{array}{l}\text { Had been used by Nicola Sabbatini in } \\
\text { France for reducing painted canvas } \\
\text { inflammation at Parisian theatres }\end{array}$ & 1638 \\
\hline $\begin{array}{l}\text { Alum- Ferrous } \\
\text { Sulfate-Borax } \\
\text { Mixture }\end{array}$ & $\begin{array}{l}\text { It was discovered by Obadiah Wyld and } \\
\text { used in Britain for preventing paper, } \\
\text { linen, canvas, \& c., from flaming or } \\
\text { retaining fire, \& c. Wyld received the } \\
\text { first patent for fire retardants No.551 }\end{array}$ & 1735 \\
\hline $\begin{array}{l}\text { Potassium } \\
\text { Aluminium } \\
\text { Sulphate (Alum) }\end{array}$ & $\begin{array}{c}\text { Used by the French brothers } \\
\text { Montgolfier to reduce flammability of } \\
\text { hot air balloons }\end{array}$ & 1783 \\
\hline $\begin{array}{l}\left(\mathrm{NH}_{4}\right)_{3} \mathrm{PO}_{4}- \\
\mathrm{NH}_{4} \mathrm{Cl} \text { - Borax } \\
\text { Mixture }\end{array}$ & $\begin{array}{l}\text { Used by the French chemist Gay-Lussac } \\
\text { for linen and hemp fabrics }\end{array}$ & 1821 \\
\hline
\end{tabular}

Table 1 A historical overview for early use of flame retardants [11-20] 1. táblázat Történeti áttekintés az égésgátlók korai használatáról [11-20]

With the development of human lifestyle, the needs to discover new materials that reduce the risk of fires have increased. This calls for relying on a scientific and practical basis and not to depend on chance only. So the first practical experiments to reduce fire risk began to appear. As a scientific 
procedure recorded, the first fire testing experiments can be traced to London's 1790s done by the Associated Architects. There was Quantitative work in Germany beginning in the 1880s, and in the U.S. and England in the 1890s. A summary of the timeline for the use of flame retardants is included in Table 1. The growing interest in these tests led to establishing unified test standards in the early twentieth century. Where the first standard about fire testing methods was ASTM C19 (later called E 199) [14-18].

\section{Categorization of flame retardants}

Flame retardants are typically categorized into four major categories: Inorganic FRs; Phosphorus-containing FRs; Nitrogen-containing FRs; and Halogenated organic.

\subsection{Inorganic flame retardants}

The most significant types of this category are antimony trioxide containing halogen, magnesium hydroxide, zinc borate, aluminium hydroxide, and zinc sulfide. If this category of flame retardant is exposed to heat, it does not evaporate. Instead, it decomposes and released non-flammable gases, such as water vapour, carbon dioxide, sulfur dioxide, hydrogen chloride, and other gases. Most of these compounds produce endothermic reactions. These flame retardants' mechanism of action depends on its disintegration at high temperatures and causing the release of non-flammable gases, which minimize the mixture of flammable gases. Then, it separates the plastic's surface by forming a glassy protective layer on the surface of the plastic that prevents oxygen and heat access [21-27].

\subsection{Phosphorus containing flame retardants}

This category typically includes phosphate esters, red phosphorus, ammonium polyphosphates, and ammonium orthophosphates. Its principle of action is based on its oxidation during combustion to phosphorus oxide, which converted into phosphoric acid when interacting with water. This acid induces the release of water and removes it from the substrate layer of the thermal decomposing material, which contributes to its decomposition and thereby increases the formation of carbonaceous waste and decreases the emission of combustible gases [28-31].

\subsection{Nitrogen containing flame retardants}

Nitrogen-containing flame retardants: Often referred to as organic flame retardants. Melamine and its derivatives are the essential compounds in this category. These retardants' principle of action depends on the formation of an insulating surface layer by gases released from these retardants during combustion cause the material to swell [32-37].

\subsection{Halogenated organic flame retardants}

This category contains primary bromine and chlorine in particular. Its principle working action depends on chemical interference with the root chain mechanism, which occurs in the gaseous phase during combustion. Halogen flame retardants eliminate the high-energy hydrogen and hydroxide generated during the combustion process by combining them, so the flame is poisoned by the halogen radicals released during combustion [21,38-41].

\section{Classification of flame retardants}

Flame retardants can be classified into three primary groups, depending on how they are applied to the polymer, and these two groups are: Additive FRs; Reactive FRs.; and AdditiveReactive FRs

\subsection{Additive flame retardants}

This type is used for thermoplastics in particular. Additive flame retardants can be added to plastics in three ways: (1) before polymerization, (2) during the process, or (3) after polymerization, and it is the most common way to add them. In addition to its direct action as flame retardants, it can be a plasticizer if they are compatible with the plastic or as fillers if they aren't compatible with it. The main disadvantage of these retardants, is their instability, where they sometimes can be volatile or even bled from the plastic, especially from the layers near the surface, causing plastic to lose its ability to resist burning, which is very dangerous because this state can only be realized when combustion occurs [42-44].

\subsection{Reactive flame retardants}

This type of flame retardant is binding to the polymer molecule with the other components. This chemical bonding prevents it from evaporating and bleeding from the polymer over time. It happens with additive flame retardants, enabling the polymer to maintain flame retardant properties as long as possible. Although they are chemically binding to the polymer molecules, they have no plasticizing effect and are non-affecting the polymer's thermal stability. The practical and widespread use of reactive flame retardants is with thermosets [41-44].

\subsection{Additive- Reactive flame retardants}

This type of flame retardants is referred to also as synergism. Several materials are not classified as stand-alone flame retardants, which will often work as fillers if used alone. Still, they have a special synergistic effect if they are added to other retardants, where the effectiveness and efficiency of these retardants increase to resist fire. An example of such materials is antimony compounds, especially antimony trioxide. The main purpose of this combination is to reduce the cost and, as mentioned, increase the effectiveness of the primary flame retardant $[21,42,43,42,45,46]$.

\section{Working mechanism of flame retardants}

The method of slowing or even stopping the flame depends on the nature of the flame retardant, as the flame retardant can act chemically or physically in the solid, liquid, and gas state, where the flame retardant is interpenetrating with the combustion process during the various stages of this process, i.e., heating, decomposition, ignition, or flame propagation $[21,47,48]$. In general, there are two standard methods of flame retardation. The first method is based on preventing oxygen 
from accessing the flame area by generating non-combustible gases, where these gases can poison and extinguish the flame with free radicals. The second method is based on the thermal flame theory, which states that flame retardants require thermal energy for decomposition, leading to a decrease in the material's surface temperature to a temperature lower than its burning point, and the combustion breaks down [49].

\subsection{Physical mode}

This working mode can be achieved in three ways [47,50,51]:

\subsubsection{Cooling}

Additives cause endothermic processes that cool the substrate of the material to a temperature lower than the level of combustion. An example of flame retardants behaving like this is aluminum hydroxide. The cooling mechanism is shown in Fig 1.

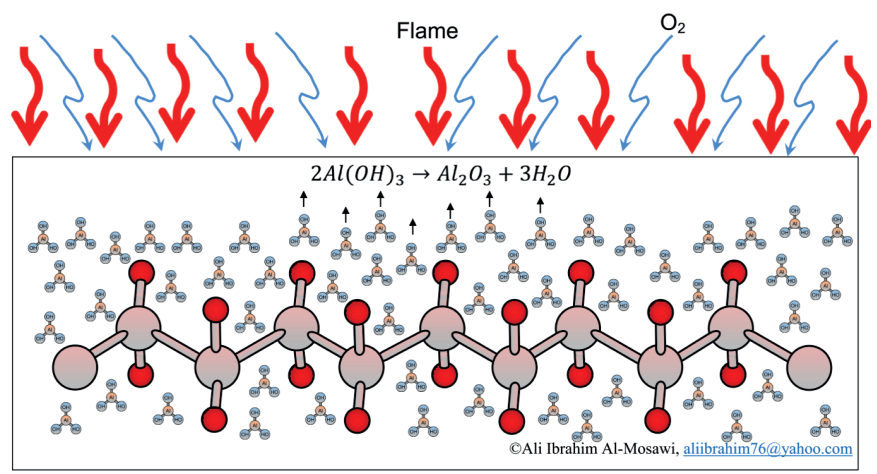

Fig. 1 Cooling mechanism

1. ábra Hütési mechanizmus

\subsubsection{Formation of insulation layer}

The insulating semi-glass layer is created by a flame retardant that expels the oxygen needed to begin the combustion process, preventing heat transfer. Inorganic phosphorous compounds and boron are behaving like this mode.

\subsubsection{Dilution}

The incorporation of inert materials (fillers) and additives that release inert gases after their thermal decomposition dilute the fuel in both the solid and gaseous states in such a way that the minimum ignition limits for the gas mixture are not exceeded. Phosphorous and boron compounds work this way.

\subsection{Chemical mode}

Can be achieved in two ways:

\subsubsection{Gaseous phase reaction}

The free radical mechanism is stopped by the flame-retardant materials, causing eliminating the exothermic processes and, so the system will cool down. The percentage of flammable gases is reduced and even wholly prohibited as shown in Fig 2. The flame retardant which exhibits this behavior is halogen compounds [21,51].
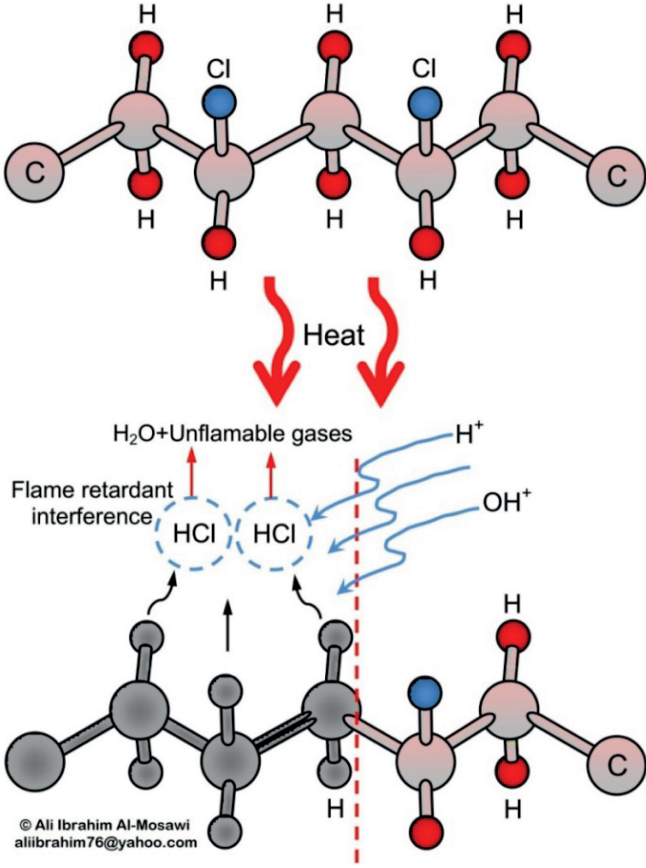

Fig. 2 Gaseous phase reaction

2. ábra Gáz-halmazállapotú fázisreakció

\subsubsection{Solid Phase Reaction}

A carbon film is formed on the surface of the polymer by the dehydrating action of flame retardant, forming double bonds in the polymer (see Fig 3). These double bonds will create a carbon film by cross-linking. An example of these retardants is phosphorous compounds. In the case of phosphorous compounds addition, their mode of action depends on substituting the hydroxyl and hydrogen radicals in the combustion cycle by low-potency radicals, eliminating their damage as shown in the equations below, which represents the combustion reaction (Chain reaction equations), and the hinderation reaction (Chain hinderation equations). This mechanism is similar to that of the halogen compounds. The change in the combustion cycle's radical composition in the gaseous phase leads to flame suppression and reduced heat production, which cools the combustion zone. The combustion process activated several sequential reactions, which include: chemical chain-branching, chain-propagating, and chainbreaking reactions. These chemical processes help preserve the flame by changing the quantity, form, and mole ratio of the radicals present in the gas phase. Therefore, in order to change this state, Lower energy radicals are required to remove the unstable radicals of $\mathrm{OH}$ and $\mathrm{H}$. Replacing the unstable $\mathrm{OH}$ and $\mathrm{H}$ radicals with less reactive and more stable radicals works to inhibit the combustion chain reaction and lead to cut this reaction. Thus the self-extinguishing process of the system will occur [21,52-54]. 


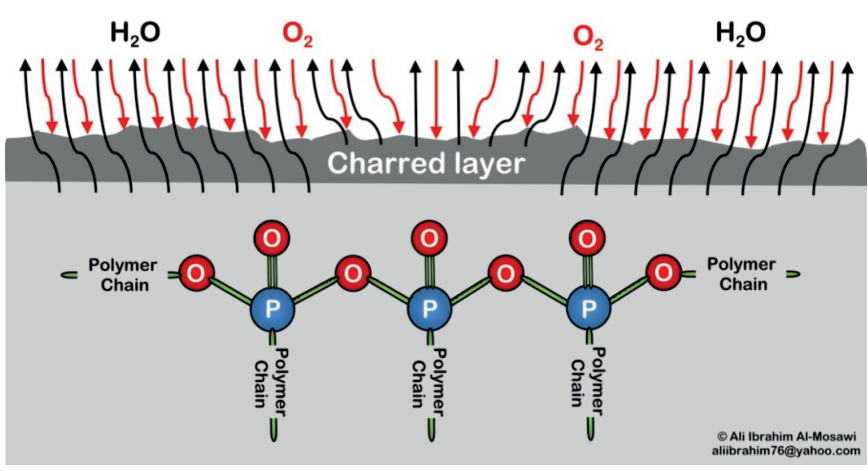

Fig. 3 Solid phase reaction

3. ábra Szilárd fázis reakció

Chain reaction equations [54]:

$\mathrm{OH}+\mathrm{CO} \rightarrow \mathrm{CO}_{2}+\mathrm{H}$

$\mathrm{CH}_{4}+\mathrm{O}_{2} \rightarrow \mathrm{CH}_{3}+\mathrm{H}+\mathrm{O}_{2}$

$\mathrm{H}+\mathrm{O}_{2} \rightarrow \mathrm{OH}+0.5 \mathrm{O}_{2}$

$\mathrm{OH}+\mathrm{CH}_{4} \rightarrow \mathrm{H}_{2} \mathrm{O}+\mathrm{CH}_{3}$

$\mathrm{CH}_{3}+\mathrm{O}_{2} \rightarrow \mathrm{CH}_{2} \mathrm{O}+\mathrm{HO}$

$\mathrm{CH}_{2} \mathrm{O}+\mathrm{HO} \rightarrow \mathrm{CHO}+\mathrm{H}_{2} \mathrm{O}$

$\mathrm{CHO}+\mathrm{O}_{2} \rightarrow \mathrm{CO}+\mathrm{H}+\mathrm{O}_{2}$

Chain hinderation equations [54]:

$\mathrm{PO}+\mathrm{H} \rightarrow \mathrm{HPO}$

$\mathrm{PO}+\mathrm{OH} \rightarrow \mathrm{HPO}_{2}$

$\mathrm{HPO}+\mathrm{H} \rightarrow \mathrm{H}_{2}+\mathrm{PO}$

$\mathrm{HPO}+\mathrm{CH}_{3} \rightarrow \mathrm{H}_{2}+\mathrm{PO}$

$\mathrm{HPO}_{2}+\mathrm{H} \rightarrow \mathrm{H}_{2} \mathrm{O}+\mathrm{PO}$

$\mathrm{HPO}_{2}+\mathrm{H} \rightarrow \mathrm{H}_{2}+\mathrm{PO}_{2}$

$\mathrm{HPO}_{2}+\mathrm{OH} \rightarrow \mathrm{H}_{2} \mathrm{O}+\mathrm{PO}_{2}$

\begin{tabular}{lcc}
\hline \multicolumn{1}{c}{ Polymer } & $\begin{array}{c}\text { Flash-ignition } \\
\text { Temperature, }{ }^{\circ} \mathbf{C}\end{array}$ & $\begin{array}{c}\text { Self-ignition } \\
\text { temperature, }{ }^{\circ} \mathbf{C}\end{array}$ \\
\hline Poly(methyl methacrylate) & 300 & 430 \\
\hline Polypropylene & 320 & 350 \\
\hline $\begin{array}{l}\text { Polyethylene } \\
\text { Polystyrene }\end{array}$ & 340 & 350 \\
\hline Rigid Poly(vinyl chloride) & 350 & 490 \\
\hline $\begin{array}{l}\text { Plasticized Poly(vinyl chloride) } \\
\text { (Insulation) }\end{array}$ & 330 & 450 \\
\hline $\begin{array}{l}\text { Plasticized Poly(vinyl chloride) } \\
\text { (Fire resistant, low acid emis- } \\
\text { sion) }\end{array}$ & 400 & 385 \\
\hline $\begin{array}{l}\text { Poly(acrylonitrile) } \\
\text { Polyamide 6'6 }\end{array}$ & 480 & 410 \\
\hline \begin{tabular}{l} 
Poly(tetrafluoroethylene) \\
\hline
\end{tabular} & 490 & 560 \\
\hline
\end{tabular}

Table 2 Flash and self ignition temperatures for various polymers [58,59] 2. táblázat Vaku-és öngyulladási hömérséklet különböző polimerekhez [58,59]

\section{Flammability and combustibility}

Many people think that flammability or ignitability and combustibility is similar in denoting the same characteristic. Still, the truth is that they are different, so I will explain what these two terms refer to in this paragraph. The flammability or ignitability is defined as a material's ability to catch fire (ignite), causing a fire, combustion, or even an explosion if the material is unstable. Whereas combustibility is defined as how easily a material burns to cause a fire or combustion [55]. The main criterion by which materials are classified as flammable or combustible is the flash point, where flammable materials have a lower flash point than combustible materials. The flash point of flammable materials is less than $37.8^{\circ} \mathrm{C}$, while in the case of combustible materials; its value is higher than $37.8^{\circ} \mathrm{C}$ and less than $93.3^{\circ} \mathrm{C}$ [55-58]. Table 2 represents the flash-ignition and self-ignition temperatures for various polymers.

\section{Flame retardants and the environment}

Most of conventional flame retardants and stabilizers for plastics contain heavy metals or other ingredients e.g., bromine being potentially harmful to the environment or health. For example, in European countries, concentrations of flame retardants have been found in human milk and the bodies of birth cohorts (but their concentrations were lower than in the United States) and household dust. Concentrations of flame retardants were also found in the bodies of birds and their eggs [60-69]. Therefore, in light of these environmental challenges and responsibilities, most of these flame retardants must be reconsidered in terms of use and finding an environmentally friendly and sustainable alternative. Especially since countries have already started issuing laws prohibiting the use of certain types of flame retardants due to their severe damage to the environment after research has proven this [70-72]. Many of flame retardants currently in use are included in European Union regulation (EC) No. 1272/2008 and its amendments for materials classification, which have been classified as dangerous materials. So it has become imperative to search for safe alternatives to these materials [73]. There are heavy metalfree flame retardants (earth metal hydroxides), but it must be used in high concentrations (40-60 phr), which in turn will reduce the mechanical properties and wear resistance of the plastic [60].

Therefore, there must be a precise harmony between environmentally friendly flame retardants and preserving the materials' properties. This matter requires more time and research for a complete shift from traditional flame retardants to those environmentally friendly [7, 60, 73-75]. Certain recent flame retardants are now available to comply with the successful flammability tests regulations. Also, the interference of retardants with flame reaction chains will restrict the oxidation of the hydrocarbon. This interference will prevent the process of converting carbon monoxide to carbon dioxide, which causes highly volatile, very smoky fire effluents and rich in incomplete combustion products [76]. With the tendency to replace traditional flame retardants with environmentally friendly ones, the environmental conditions surrounding the product containing this type of retardants must be taken into account and the applications for which it is used. One study revealed that environmentally friendly retardants could be harmful when breaking down by heat and ultraviolet rays [77]. Therefore, it is necessary to use these retardants carefully. Obtaining the ideal flame retardant requires great research efforts that may not take as long as research in the past due 
to scientific research development. Whereas the chemical stability of environmentally friendly flame retardants in different conditions is of critical importance to increase safety level when using these retardants.

\section{Conclusions}

Every year, flame retardants save thousands of lives around the world. Still, unfortunately, many also lose their lives because many of these retardants are made from harmful components to both health and the environment. Many legislations and laws have restricted the use of flame retardants containing heavy metals, which will make the heavy metalsfree ones (green flame retardants) commonly used. To obtain the maximum effectiveness of flame retardants, each type must be used with the appropriate material intended to improve its flame resistance.

\section{References}

[1] Al-Mosawi, A.I. and Marossy, K. (2018): Heat Effected Zone in Unburned, Antimony Trioxide Containing Plasticized Poly(vinyl chloride). Építőanyag-Journal of Silicate Based and Composite Materials, Vol.70, No.3, pp.86-89.

https://doi.org/10.14382/epitoanyag-jsbcm.2018.16

[2] Winberg, D. (2016): International Fire Death Rate Trends, SP Technical Research Institute of Sweden. Report No.32. ISBN: 978-91-88349-36-1

[3] Al-Mosawi, A.I. (2011): Hybrid Fire Retardants to Increasing Composting Resistance for Fibres-Reinforced Composites. Iraqi National Journal Of Chemistry, Vol. 41, pp 48-54. https://doi.org/10.6084/m9.figshare.13550177

[4] Velasquez, K. and Viani, T. (2006): Flame Retardants Families. Capstone Design Project, University of Oklahoma, Chemical Engineering.

[5] Al-Mosawi, A.I. (2021): Flame Retarding-Stabilizing Behavior of Plasticized Poly(vinyl chloride) Containing Novel Heavy Metal Free Modifier. PhD dissertation, Faculty of Material Science and Engineering, University of Miskolc, Hungary.

[6] Levchik, S.V. (2006) Introduction to Flame Retardancy and Polymer Flammability. Chapter 1, In: Morgan, A. and Wilkie Ch.(eds.), Flame Retardant Polymer Nanocomposites. John Wiley \& Sons, Inc., pp. 1-29. https://doi.org/10.1002/9780470109038.ch1

[7] Babrauskas V. et al. (2020): Fire Hazard Comparison of Fire Retarded and Non-Fire-Retarded Products. Kindle Edition, NBS Special Publications No.749. ASIN: B084TZMN2N

[8] Hilado, C.J. (1998): Flammability Handbook for Plastics. $5^{\text {th }}$ Edition, CRC Press: Boca Raton. https://doi.org/10.1201/9780585248684

[9] Liu, Q. et al. (2020): Recent Developments in the Flame-Retardant System of Epoxy Resin, Materials. Vol.13, Issue. 9, pp.2145. https://doi.org/10.3390/ma13092145

[10] Al-Mosawi, A.I., Amash, H.K. Al-Maamori, M.H., and Hashim, A.A. (2014): Enhancement of thermal resistance of aircraft tires by using magnesium hydroxide. Central Organization for Standardization and Quality Control (COSQC), No.3877, International Classification (B608C13/00), Iraqi Classification (34).

[11] Hindersinn, R.R. (1990): Historical Aspects of Polymer Fire Retardance. Chapter 7, In: Gordon L. Nelson, G. (ed.) Fire and Polymers: Hazards Identification and Prevention, ACS Symposium Series, Vol. 425, American Chemical Society, pp 87-96. https://doi.org/10.1021/bk-1990-0425.ch007

[12] Watson, D.A.V. and Schiraldi, D.A. (2020): Biomolecules as Flame Retardant Additives for Polymers: A Review. Polymers, Vol.12, Issue.4, 2020, pp.849 (31 pages). https://doi.org/10.3390/polym12040849

[13] Kozlowski, R. and Wladyka-Przybylak, M. (2001): Natural Polymers, Wood and Lignocellulosic Materials. Chapter 9, In: Horrocks, A., Price, D. (eds.) Fire Retardant Materials, Woodhead Publishing Limited, UK, pp.305-317.
[14] Brown, F. L. (1958): Theories of the combustion of wood and its control: A Survey of the Literature. Forest Service Report No.2136, Forest Products Laboratory, Madison Wis., in cooperation with the University of Wisconsin.

[15] Gay-Lussac, J.L (1821): Note sur la propriete qu'ont les matieres salines de rendre les tissus incombustibles (Note on the property that saline materials have to make tissues incombustible). Annales de chimie et de physique, Vol.18, pp.211-261.

[16] Babrauskas, V. and Williamson, R.B. (1978): The historical basis of fire resistance testing - Part I. Fire Technology vol.14, Issue.3, pp.184-194. https://doi.org/10.1007/BF01983053

[17] Babrauskas, V. and Williamson, R.B., (1978): The historical basis of fire resistance testing - Part II. Fire Technology vol.14, Issue.4, pp. 304-316. https://doi.org/10.1007/BF01998390

[18] Hall, J.R. (2004): A Century of Fire Standards: The History of Committee E05, 1904-2004. ASTM Standardization News, ASTM International.

[19] Lawson, J.R. (2009): A History of Fire Testing, NIST Technical Note 1628. National Institute of Standards and Technology, U.S. Department of Commerce.

[20] Wyld, O. (1735): Making or Preparing of Paper, Linen, Canvass and Such Like Substances, Which Will Neither Flame nor Retain Fire, and Which Hath Also a Property in it of Resisting Moisture and Damps. British Patent No.551, London.

[21] Al-Mosawi, A.I. (2003): Using Study of Antimony Trioxide Material as a Flame Retardant Material. M. Sc. Thesis, Engineering College, Babylon University, Iraq. https://doi.org/10.13140/RG.2.1.4718.1529

[22] Lawson, J.R. (2009): A History of Fire Testing: Past, Present, and Future. Journal of ASTM International, Vol. 6, No.4, pp. 1-19. https://doi.org/10.1520/JAI102265

[23] Ai, L., Chen, S., Yang, L. and Liu, P. (2021): Synergistic Flame Retardant Effect of Organic Boron Flame Retardant and Aluminum Hydroxide on Polyethylene. Fibers and Polymers, Vol.22, Issue.2, pp.354-365. https://doi.org/10.1007/s12221-021-9385-6

[24] Walter, M.D. and Wajer, M.T. (2015): Overview of Flame Retardants Including Magnesium Hydroxide. Martin Marietta Magnesia Specialties LLC, Maryland, USA.

[25] Al-Mosawi, A.I. et al. (2010): Performance Evaluation of Zinc Borate to improvement thermal properties of Antimony Trioxide at Elevated Temperatures. The Iraqi Journal for Mechanical and Material Engineering, Special Issue for $2^{\text {nd }}$ scientific conference, engineering College, University of Babylon, Iraq, 24-25 March. https://doi.org/10.6084/m9.figshare.16548054

[26] Luo, H. et al. (2020): An Efficient Organic/Inorganic PhosphorusNitrogen-Silicon Flame Retardant Towards Low-Flammability Epoxy Resin. Polymer Degradation and Stability, Vol.178, pp. 1-9. https://doi.org/10.1016/j.polymdegradstab.2020.109195

[27] Al-Mosawi, A.I., Ammash, H.K., Al-Maamori, M.H., and Hashim, A.A (2012): Increasing flammability resistance for aircrafts tires by using magnesium hydroxide. Academic Research International, Vol.3, No.2, pp. 11-14. https://doi.org/10.6084/m9.figshare.16547274

[28] Al-Mosawi, A.I. (2012): Formation Hybrid Flame Retardant and its Effect on Thermal Resistance of Araldite resin Composite. Academic Research International, Vol.3, Issue.2, pp. 66-69.

https://doi.org/10.6084/m9.figshare.13633481

[29] Huo, S. et al. (2020): A Liquid Phosphorus-Containing Imidazole Derivative as Flame-Retardant Curing Agent for Epoxy Resin with Enhanced Thermal Latency, Mechanical, and Flame-Retardant Performances. Journal of Hazardous Materials, Vol.386, pp.121984. https://doi.org/10.1016/j.jhazmat.2019.121984

[30] Al-Mosawi, A.I. (2012): Flame Retardancy of Polymers. $1^{\text {st }}$ Edition, LAP LAMBERT Academic Publishing, Germany. ISBN: 25531 -659 -3-978

[31] Zhang, W. et al. (2014): The Influence of the Phosphorus-Based Flame Retardant on the Flame Retardancy of the Epoxy Resins. Polymer Degradation and Stability, Vol.109, pp.209-217. https://doi.org/10.1016/j.polymdegradstab.2014.07.023

[32] Levchik, S. (2014): Phosphorus-Based FRs. Chapter 2, In: Morgan, A. and Wilkie Ch.(eds.), Non-Halogenated Flame Retardant Handbook, John Wiley and Sons, Inc., pp. 17-74. https://doi.org/10.1002/9781118939239.ch2 
[33] Horacek, H. and Pieh, S. (2000): The Importance of Intumescent Systems for Fire Protection of Plastic Materials. Polymer International, Vol.49, Issue.10, pp. 1114-1106.

https://doi.org/10.1002/1097-0126(200010)49:10<1106::AID PI539>3.0.CO;2-I

[34] Çetin, A. et al. (2019): Various Combinations of Flame Retardants for Poly (vinyl chloride). Open Chemistry, Vol.17, Issue.1, pp.980-987. https://doi.org/10.1515/chem-2019-0105

[35] Ray, S.S.and Kuruma, M. (2019): Types of Flame Retardants Used for the Synthesis of Flame-Retardant Polymers. Chapter 4 In: Ray, S., Kuruma, M. (auth.) Halogen-Free Flame-Retardant Polymers Springer Series in Materials Science, Springer, Cham., Vol 294, pp.15-45. https://doi.org/10.1007/978-3-030-35491-6_4

[36] Duquesne, S. and Futterer, T. (2014): Intumescent Systems, Chapter 8, In: Morgan, A. and Wilkie Ch.(eds.), Non-Halogenated Flame Retardant Handbook. Co-published by CoJohn Wiley and Sons, Inc. And Scrivener Publishing LLC., USA, pp. 293-346. https://doi.org/10.1002/9781118939239.ch8

[37] Wang, J. et al. (2020): A Novel Intumescent Flame Retardant Imparts High Flame Retardancy to Epoxy Resin. Polymers for Advanced Technologies, Vol.31, Issue.5, pp.932-940. https://doi.org/10.1002/pat.4827

[38] Al-Mosawi, A.I. (2016): Flammability of Composites. Chapter 14, In: Njuguna, J. (ed.) Lightweight Composite Structures in Transport: Design, Manufacturing, Analysis and Performance, Woodhead Publishing, UK, pp. 361-369. https://doi.org/10.1016/B978-1-78242-325-6.00014-1

[39] Klatt, M. (2014): Nitrogen-Based Flame Retardants. Chapter 4, In: Morgan, A. and Wilkie Ch.(eds.), Non-Halogenated Flame Retardant Handbook, John Wiley and Sons, Inc., pp. 143-168. https://doi.org/10.1002/9781118939239.ch4

[40] Guerra, P. et al. (2011): Introduction to Brominated Flame Retardants: Commercially Products, Applications, and Physicochemical Properties. chapter 1, In Eljarrat, E., Barceló, D., Brominated Flame Retardants The Handbook Of Environmental Chemistry, $1^{\text {st }}$ Edition, Springer Berlin Heidelberg, Germany, pp.1-17. https://doi.org/10.1007/698_2010_93

[41] Vahabi, H. et al. (2021): Flame Retardancy of Reactive and Functional Polymers. Chapter 8, In: Gutiérrez, T. (ed.) Reactive and Functional Polymers, Vol.3, Springer Nature Switzerland AG, pp. 165-195. https://doi.org/10.1007/978-3-030-50457-1_8

[42] Lens, J., Sun, X. and Kagumba, L. (2019): Polymeric Flame Retardants for Reinforced Thermoplastic and Thermoset Resins. Reinforced Plastics, Vol.63, Issue.1, pp.36-39. https://doi.org/10.1016/j.repl.2017.11.016

[42] Lassen, C. et al. (1999): Brominated Flame Retardants: Substance Flow Analysis and Assessment of Alternatives, Environmental Project, Danish Environmental Protection Agency. ISBN: 87-7909-416-3

[44] Baby, A. et al. (2020): Reactive and Additive Modifications of Styrenic Polymers with Phosphorus-Containing Compounds and Their Effects on Fire Retardance. Molecules, Vol.25, Issue.17, pp.3779. https://doi.org/10.3390/molecules25173779

[45] Adewale, K.P. (2016): Thermoplastic Additives Flame Retardants. Chapter 26, In: Olabisi, O., Adewale, K. (eds.) Handbook of Thermoplastics, $2^{\text {nd }}$ Edition, CRC Press, pp. 877-917. https://doi.org/10.1201/b19190-27

[46] Al-Mosawi, A.I. et al. (2010): Effect of Compilation Between Two Types of Inorganic Flame Retardants on Thermal Resistance for Advanced Composite Material at Elevated Temperatures. Proceedings of $5^{\text {th }}$ Scientific Conference (CSASC 2010), College of Science, University of Babylon, Iraq, 19-20 May, pp.448-455.

https://doi.org/10.6084/m9.figshare. 13633760

[47] Zirnstein, B. et al. (2019): Combination of Phosphorous Flame Retardants and Aluminum Trihydrate in Multicomponent EPDM Composites. Polymer Engineering and Science, Vol.60, Issue.2, pp.267-280. https://doi.org/10.1002/pen.25280

[48] Troitzsch, J.H. (1998): Overview of Flame Retardants . Chimica Oggi/ Chemistry Today, Vol.16, No.1, pp.18-24.

[49] Hu, Y. and Wang, X. (2019): Flame Retardant Polymeric Materials: A Handbook. $1^{\text {st }}$ Edition, CRC Press, USA. https://doi.org/10.1201/b22345

[50] Mohammed, A.A. (1993): Plastics Chemistry. $1^{\text {st }}$ Edition, House of Books for Printing and Publishing - Mosul, Iraq.
[51] Tawfik, S.Y. (2017): Flame Retardants: Additives in Plastic Technology. Chapter 15, In: Palsule S. (eds.) Polymers and Polymeric Composites: A Reference Series. Springer, Berlin, Heidelberg, pp.1-27. https://doi.org/10.1007/978-3-642-37179-0_76-2

[52] Salmeia, K.A. et al. (2015): An Overview of Mode of Action and Analytical Methods for Evaluation of Gas Phase Activities of Flame Retardants. Polymers, Vol.7, Issue.3, pp.504-526.

https://doi.org/10.3390/polym7030504

[53] Schartel, B. (2010): Phosphorus-based Flame Retardancy MechanismsOld Hat or a Starting Point for Future Development?. Materials, Vol.3, Issue.10, pp. 4710-4745. https://doi.org/10.3390/ma3104710

[54] Lazar, S.T. et al. (2020): Flame-Retardant Surface Treatments. Nature Reviews Materials, Vol.5, Issue.4, pp.259-275. https://doi.org/10.1038/s41578-019-0164-6

[55] Goodger, E.M. (1979): Flammability and Ignitability. Applied Energy, Vol.5, Issue.1, pp.81-84. https://doi.org/10.1016/0306-2619(79)90007-2

[56] Burton, L. (2019): What Are the Key Differences Between Flammable and Combustible Materials?. High Speed Training Ltd., UK.

[57] Dickens, E.D. (1983): The Fire Performance of PVC. Journal of Vinyl Technology, Vol.5, Issue.3, pp.150-157. https://doi.org/10.1002/vnl.730050315

[58] Pawelec, W. (2014): New Families of Highly Efficient, Halogen-Free Flame Retardants for Polypropylene (PP). Doctoral Thesis, Åbo Akademi University, Finland.

[59] PVC and Fire (2011): Poly Marketing Pty Limited T/A Envorinex company, Australia.

[60] Al-Mosawi, A.I. and Marossy, K. (2020): Heavy Metal Free Thermal Stabilizing-flame Retarding Modifier for Plasticized Poly(vinyl chloride). Materials Research Express, Vol.7, Issue.1, pp. 015320. https://doi.org/10.1088/2053-1591/ab6249

[61] Čechová, E. et al. (2017): Legacy and Alternative Halogenated Flame Retardants in Human Milk in Europe: Implications for Children's Health. Environment International, Vol.108, pp.137-145. https://doi.org/10.1016/j.envint.2017.08.008

[62] Casas, M. et al. (2013): Exposure to Brominated Flame Retardants, Perfluorinated Compounds, Phthalates and Phenols in European Birth Cohorts: ENRIECO Evaluation, First Human Biomonitoring Results, and Recommendations. International Journal of Hygiene and Environmental Health, Vol. 216, Issue.3, pp.230-242. https://doi.org/10.1016/j.ijheh.2012.05.009

[63] dela Torre, A. et al. (2020): Organophosphate Compounds, Polybrominated Diphenyl Ethers and Novel Brominated Flame Retardants in European Indoor House Dust: Use, Evidence for Replacements and Assessment of Human Exposure. Journal of Hazardous Materials, Vol.382, pp.121009. https://doi.org/10.1016/j.jhazmat.2019.121009

[64] Lee, H. et al. (2020): Legacy and Novel Flame Retardants in Water and Sediment from Highly Industrialized Bays of Korea: Occurrence, Source Tracking, Decadal Time Trend, and Ecological Risks. Marine Pollution Bulletin, Vol.160, pp.111639. https://doi.org/10.1016/j.marpolbul.2020.111639

[65] Venier, M. et al. (2014): Flame retardants and legacy chemicals in Great Lakes' water. Environmental Science and Technology, Vol.48, Issue.16, pp.9563-72. https://doi.org/10.1021/es501509r

[66] Liu, J. et al. (2021): Legacy and Alternative Flame Retardants in Typical Freshwater Cultured Fish Ponds of South China: Implications for Evolving Industry and Pollution Control. Science of The Total Environment, Vol.763, pp.143016. https://doi.org/10.1016/j.scitotenv.2020.143016

[67] Zhang, J. et al. (2021): Pollution of Plastic Debris and Halogenated Flame Retardants (HFRs) in Soil from an Abandoned E-Waste Recycling Site: Do Plastics Contribute to (HFRs) in Soil?. Journal of Hazardous Materials, Vol. 410, pp.124649. https://doi.org/10.1016/j.jhazmat.2020.124649

[68] Wang, Y. et al. (2021): Ornamental Houseplants as Potential Biosamplers for Indoor Pollution of Organophosphorus Flame Retardants. Science of The Total Environment, Vol. 767, pp.144433. https://doi.org/10.1016/j.scitotenv.2020.144433

[69] Barhoumi, B. et al. (2020): Halogenated Flame Retardants in Atmospheric Particles from a North African Coastal City (Bizerte, Tunisia): Pollution Characteristics and Human Exposure. Atmospheric Pollution Research, Vol.11, Issue. 4, pp.831-840. https://doi.org/10.1016/j.apr.2020.01.011 
[70] Jarosinski, A. et al. (2020): New Production Route of Magnesium Hydroxide and Related Environmental Impact. Sustainability, Vol.12, Issue. 21, pp.8822. https://doi.org/10.3390/su12218822

[71] Gebke, S. et al. (2020): Suitability and Modification of Different Renewable Materials as Feedstock for Sustainable Flame Retardants. Molecules, Vol.25, Issue.21, pp.5122. https://doi.org/10.3390/molecules25215122

[72] González-Rubio, S. et al. (2021): A Review on Contaminants of Emerging Concern in European Raptors (2002-2020). Science of The Total Environment, Vol.760, pp.143337.

https://doi.org/10.1016/j.scitotenv.2020.143337

[73] European Parliament and Council of the European Union (2008): Regulation (EC) No 1272/2008 of the European Parliament and of the Council of 16 December 2008 on Classification, Labelling and Packaging of Substances and Mixtures, Amending And Repealing Directives 67/548/ EEC and 1999/45/EC, and Amending Regulation (EC) No 1907/2006, Official Journal of the European Union, Vol.51.

[74] Zhang, A. et al. (2021): Construction Of Durable Eco-Friendly BiomassBased Flame-Retardant Coating For Cotton Fabrics. Chemical Engineering Journal, Vol.410, pp.128361. https://doi.org/10.1016/j.cej.2020.128361
[75] Li, N. et al. (2020): Novel Eco-Friendly Flame Retardants Based on Nitrogen-Silicone Schiff Base and Application in Cellulose. ACS Sustainable Chemistry and Engineering, Vol.8, Issue.1, pp.290-301. https://doi.org/10.1021/acssuschemeng.9b05338

[76] Kausar, A. (2019): Fire Protection: Flame-Retardant Polymers in. Chapter 61, In: Mishra, M. (ed.) Encyclopedia of Polymer Applications, First Edition, CRC Press, Taylor \& Francis Group, USA, pp.1258-1272. https://doi.org/10.1201/9781351019422-140000019

[77] Koch, C. et al. (2019): Degradation of the Polymeric Brominated Flame Retardant "Polymeric FR" by Heat and UV Exposure, Environmental Science and Technology, 2019, Vol.53, Issue.3, pp.1453-1462. https://doi.org/10.1021/acs.est.8b03872

Ref.:

Al-Mosawi, Ali I.: Flame retardants, their beginning, types, and environmental impact: a review Építỏanyag - Journal of Silicate Based and Composite Materials, Vol. 74, No. 1 (2022), 2-8. p. https://doi.org/10.14382/epitoanyag-jsbcm.2022.1

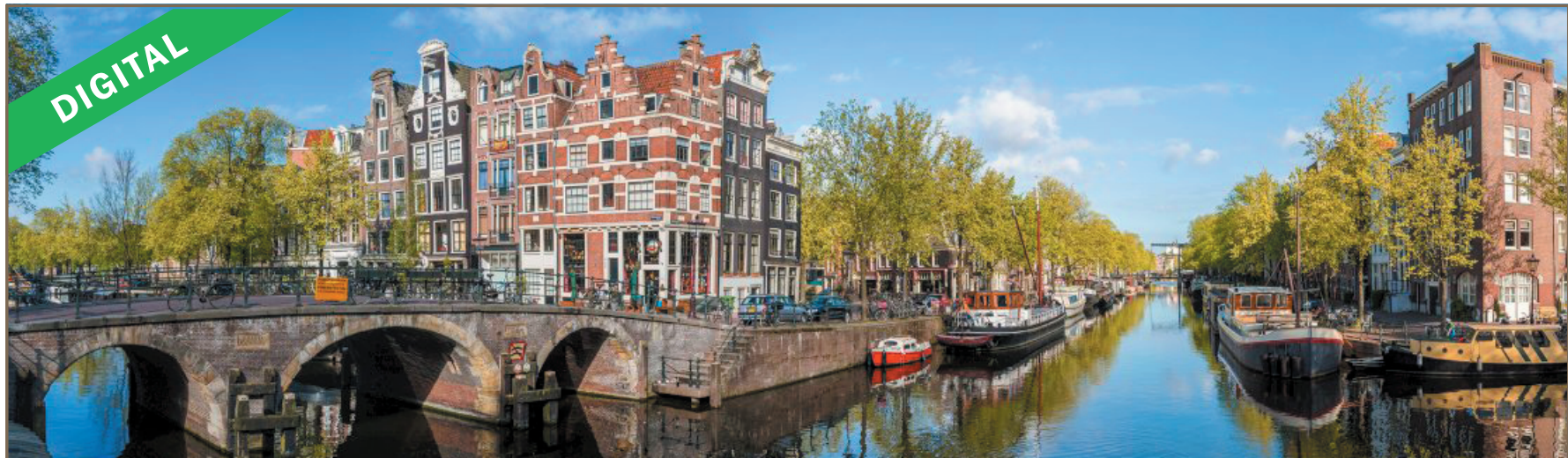

\section{ICCM 2022 \\ XVI. International Conference on Composite Materials August 08-09, 2022 in Amsterdam, Netherlands}

XVI. International Composite Materials is the premier interdisciplinary forum for the presentation of new advances and research results in the fields of Materials and Metallurgical Engineering.

Today more than ever before it is extremely important to stay abreast of the changing landscapes of the Materials and Metallurgical Engineering world. The multidisciplinary focus of this event aims to bring together presenters and attendees from different fields with expertise in various areas of Materials and Metallurgical Engineering, providing an excellent opportunity to participate in the international exchange of ideas, current strategies, concepts and best practices, collaborations, and cooperation, offering a broader perspective and more enriching experience.

The program includes time allocated for networking, peer-to-peer discussions, and exploring the host city.

We invite the participation of leading academic scientists, researchers and scholars in the domain of interest from around the world to submit original research contributions relating to all aspects of:

- Additive manufacturing

- Applications

- Bio-based composites

- Biomimetic composites

- Ceramic matrix composites

- Concrete and cementitious composites

- Damage and fracture

- Durability and ageing

- Experimental techniques

- Fibers and matrices

- FRP reinforced concrete

- Health monitoring

- Hybrid composites
- Infrastructure

- Interfaces and interphases

- Interlaminar reinforcements

- Joint and bearing behaviour

- Life cycle analysis and sustainability

- Low cost technologies

- Mechanical and physical properties

- Metal matrix composites

- Multifunctional composites

- Multiscale modelling

- Nanocomposites

- Nanotechnologies

- NDE technologies
- Polymer matrix composites

- Probabilistic approaches and design

- Processing and manufacturing technologies

- Recycling

- Repair technologies

- Sandwich technologies

- Standardisation

- Structural design

- Testing and characterization

- Textile composites 